\title{
Publication of Articles on Review of Laws and Policies
}

\section{David Ackah $^{1 \text { (corresponding author) }}{ }^{\text {, Suparji }}{ }^{2}$, Arief Budiono ${ }^{3}$}

${ }^{1}$ Institute of Project Management Professionals, Ghana; drdavidackah@gmail.com

${ }^{2}$ Poltekkes Kemenkes Surabaya, Indonesia; suparjiyozabri@gmail.com

${ }^{3}$ Faculty of Law, Universitas Muhammadiyah Surakarta, Indonesia; areevahims@gmail.com

Submitted: January 31, 2020 - Revised: January 31, 2020 - Accepted: January 31, 2020 - Published: January 31, 2020

\section{EDITORIAL}

We all know that AloHA International Journal of Mulitidisciplinary Advancement (AIJMU) is an international journal that publishes various articles from various disciplines. At the start of this second year of publication, articles on law and policy were published. We on behalf of the editorial board hope that in the next issues articles on law and policy will continue to color this journal. For this reason, we invite researchers who are engaged in the field of law and policy to publish their best research results and thoughts in this journal. 